\title{
PERTUMBUHAN STEK KRISAN (Chrysanthemum morifolium (L.) Ramat) PADA BERBAGAI MEDIA KULTUR IN VITRO
}

\author{
Adven Kristianti ${ }^{1}$, Kamsinah $^{1}$, Murni Dwiati ${ }^{1}$ \\ ${ }^{1}$ Fakultas Biologi Universitas Jenderal Soedirman, Purwokerto \\ e-mail: adven.kristianti@gmail.com
}

\begin{abstract}
Chrysanthemum (Chrysanthemum morifolium (L.) Ramat is one of ornamental plant commodities with high aesthetic value. As a consequence of increasing demand, the availability of seeds in adequate number is needed with method in vitro. This study aims to find out the effect of various in vitro culture media on the growth of chrysanthemum explants and to determine alternative media other than MS for in vitro growth of chrysanthemum explants. Experimental method arranged in a Randomized Complete Block Design (RCBD) with four treatments and four blocks is applied. The treatments are Murashige and Skoog (MS), Vacint and Went (VW), Knudson and modified media, while node position serves as block. Time of shoot emergence, shoot length, number of leaves on each shoot, and number of roots are measured. Data are analyzed using Analysis of Variance ( $F$ test) with confidence intervals of $95 \%$ and 99\%. Least Significant Difference (LSD) test is applied when significant difference among variables is observed. Culture media shows significant effect on chrysanthemum explant in vitro growth. Knudson media is found as an alternative media besides MS sufficiently suitable to increase chrysanthemum explants in vitro growth.
\end{abstract}

Key words: chrysanthemum, micropropagation, alternative media

\section{Abstrak}

Bunga krisan (Chrysanthemum morifolium (L.)Ramat merupakan salah satu komoditas tanaman hias yang memiliki nilai estetika.Sebagai konsekuensi meningkatnya permintaan bunga krisan diperlukan bibit krisan dalam jumlah yang memadai dengan metode in vitro.Penelitian ini bertujuan untuk mengetahui pengaruh berbagai media kulturin vitro terhadap pertumbuhan stek tanaman krisan dan menentukan media alternatif selain media MS bagi pertumbuhan stek krisan.Metode yang digunakan adalah eksperimental dengan Rancangan Acak Kelompok (RAK).Perlakuan yang digunakan adalah media Murashige \& Skoog (MS), media Vacint \& Went (VW), media Knudson, dan media modifikasi. Sebagai kelompok atau blok digunakan letak ruas batang. Parameter yang diamati adalah waktu munculnya tunas, panjang tunas, jumlah daun pada tunas, dan jumlah akar.Data yang diperoleh dianalisis menggunakan Analisis Ragam (uji F) dengan taraf kepercayaan 95\% dan 99\%.Apabila perlakuan berpengaruh nyata, maka dilakukan uji lanjut dengan uji Beda Nyata Terkecil (BNT). Media kultur berpengaruh terhadap pertumbuhan stek tanaman krisan secara in vitro. Media Knudson merupakan media alternatif selain media MS yang cukup baik dalam meningkatkan pertumbuhan stek tanaman krisan secara in vitro.

Key words: chrysanthemum, mikropropagasi, media alternatif

\section{Pendahuluan}

Bunga krisan (Chrysanthemum morifolium (L.) Ramat) merupakan tanaman hias yang dikenal pula sebagai Golden Flower (Purwanto dan Martini, 2009). Menurut Marwoto (2005) krisan merupakan komoditas bunga yang populer saat ini, karena memiliki keunggulan antara lain, memiliki bentuk dan tipe yang beragam.Karena tanaman krisan memiliki bentuk, ukuran, dan warna bunga yang bervariasi, maka krisan sangat disenangi konsumen.Puspitasari (2009) menambahkan bahwa tanaman krisan dapat dijadikan sebagai bunga potong, karena umumnya vase life bunga krisan potong dapat bertahan selama 10 hari. Selain itu, bunga krisan dapat pula dijadikanelemen dalam dekorasi ruangan dantanaman pot, sebagai penghias meja kantor, hotel serta ruangan.

Permintaan bunga potong krisan baik di pasar domestik maupun pasar internasional yang meningkat,harus diimbangi oleh penyediaan bibit krisan.Menurut Sanjaya (1996) dalam rangka mengembangkan dan membudidayakan krisan, diperlukan teknik kulturin vitro. Manfaat penggunaan teknikkulturin vitro dapat digunakan 
untuk memproduksi bibit krisan yang berkualitas danmendapatkan bibit dalam jumlah besar dalam waktu yang relatif singkat.Beberapa faktor yang mendukung keberhasilan dalam teknik kulturin vitro adalah media, zat pengatur tumbuh (ZPT),

dan faktor lingkungan seperti cahaya, kelembapan, dan suhu.

Macam-macam media yang biasa digunakan dalam kulturin vitro antara lain, media Murashige and Skoog (MS), Vacint and Went (V\&W), media Gamborg, Knudson, White, Woody Plant Medium (WPM), dan media modifikasi. Dixon (1985) berpendapat bahwa media yang umum digunakan untuk menumbuhkan krisan adalah media Murashige and Skoog (MS).Media MS merupakan media dengan kandungan nutrisi yang lengkap.Media Murashige and Skoog (MS) mengandung unsur hara makro, hara mikro, vitamin, karbohidrat, asam amino, dan zat pengatur tumbuh. Selain media MS perlu dicari media tumbuh lain, seperti misalnya media Vacint and Went (VW), Knudson, dan media modifikasi, agar dapat diketahui media pertumbuhan yang cocok bagi pertumbuhan stek krisan. Masingmasing media tumbuh perlu ditambahkan arang aktif, air kelapa, dan kentang.Penambahan arang aktif berfungsi untuk menyerap senyawa toksik, sedangkan air kelapa berfungsi sebagai zpt alami dan kentang sebagai sumber energidalam media kulturin vitro.

Berdasarkan uraian di atas maka muncul permasalahan yang perlu dikaji, yakni bagaimana pengaruh berbagai media kultur terhadap pertumbuhan stek tanaman krisan secara in vitro dan mencari media alternatif selain media MS yang paling baik bagi pertumbuhan stek tanaman krisan secara in vitro. Tujuan penelitian ini adalah untuk mengetahui pengaruh berbagai media kulturterhadap pertumbuhan stek tanaman krisan secara in vitro.Menentukan media alternatif selain media MS yang terbaik bagi pertumbuhan stek tanaman krisan secara in vitro.

\section{Metode Penelitian}

Penelitian dilaksanakan di Laboratorium Fisiologi Tumbuhan Fakultas Biologi Universitas Jenderal Soedirman Purwokerto, dari bulan Maret hingga Mei 2015.

Metode penelitian yang digunakan adalah metode eksperimental menggunakan Rancangan Acak Kelompok (RAK). Perlakuan yang digunakan terdiri atas 4 macam media, yaitu media Murashige and Skoog (MS), media Vacint and Went (V\&W), media Knudson, dan media modifikasi. Eksplan yang digunakan adalah stek dengan satu daun.Daun paling ujung dibuang. Pembagian blok didasarkan pada letak ruas batang. Ruas batang pertama sebagai blok pertama, kemudian disusul ruas dibawahnya sebagai blok kedua, blok ketiga, dan blok keempat, sehingga terdapat 16 satuan percobaan.
Parameter yang diamati adalah saat munculnya tunas (hari), saat munculnya akar(hari), panjang tunas (cm), jumlah daun pada tunas dan jumlah akar(cm). Parameter pendukung meliputi intensitas cahaya, suhu, dan kelembaban udara.

\section{Cara Kerja \\ Pembuatan Media Murashige and Skoog (MS)}

Pembuatan media Murashige and Skoog

(MS) dilakukan dengan cara menimbang bahanbahan yang diperlukan untuk membuat larutan stok $A$, larutan stok $B$, larutan stok $C$, larutan stok $D$, dan FeEDTA. Pengambilan masing-masing larutan stok yang digunakan untuk membuat 1000 $\mathrm{ml}$ media MS adalah sebagai berikut, larutan stok A sebanyak $100 \mathrm{ml}$, stok $B$ sebanyak $0,1 \mathrm{ml}$, stok C sebanyak 0,1 ml, stok $D$ sebanyak $0,05 \mathrm{ml}$, dan stok $\mathrm{E}$ sebanyak 0,1 ml. Kemudian, air kelapa ditambahkan $150 \mathrm{ml}$ dan gula sebanyak $20 \mathrm{~g}$. Setelah itu, akuades ditambahkan hingga volume larutan $980 \mathrm{ml}$. Media dihomogenkan menggunakan magnetic stirrer. $\mathrm{pH}$ media diukur sebesar 5,8. Apabila media terlalu asam, maka ditambah $\mathrm{NaOH}$ 1N.Namun, jika terlalu basa, media dapat ditambah dengan $\mathrm{HCl} 1 \mathrm{~N}$. Selanjutnya, agar dimasukkan sebanyak $8 \mathrm{~g}$ dan arang $1 \mathrm{~g}$. Akuades ditambahkan hingga volume media mencapai 1000 ml. Media dipanaskan sampai mendidih. Selanjutnya, masing-masing botol kultur yang telah disterilisasi diisi media sebanyak $50 \mathrm{ml}$. Botol kultur ditutup dengan alumunium foil dan diikat dengan karet gelang.

Data yang diperoleh dianalisis menggunakan Analisis Ragam (Uji F) dengan taraf kepercayaan $95 \%$ dan 99\%.Apabila hasilnya berpengaruh nyata, maka dilanjutkan dengan uji Beda Nyata Terkecil (BNT).

\section{Pembuatan Media VW}

Pembuatan media dilakukan dengan cara menimbang bahan-bahan kimia yang digunakan untuk membuat larutan stok $A$ dan larutan stok $B$ pada media V\&W sebanyak $1000 \mathrm{ml}$. Pengambilan larutan stok A dan larutan stok B masingmasingsebanyak100ml. Kemudian, air kelapa ditambahkan sebanyak $150 \mathrm{ml}$, gula sebanyak $20 \mathrm{~g}$, dan kentang $150 \mathrm{~g}$. Setelah itu, media ditambahdengan akuades hingga volumenya sebesar $980 \mathrm{ml}$. Media dihomogenkan menggunakan magnetic stirrer. $\mathrm{pH}$ media diukur sebesar 5,8. Apabila media terlalu asam, maka ditambah $\mathrm{NaOH}$ 1N.Namun, jika terlalu basa maka dapat ditambah dengan $\mathrm{HCl} 1 \mathrm{~N}$. Selanjutnya, agar dimasukkan sebanyak $8 \mathrm{~g}$ dan arang sebanyak $1 \mathrm{~g}$. Akuades ditambahkan hingga volume media mencapai $1000 \mathrm{ml}$. Media dipanaskan sampai mendidih. Selanjutnya, masing-masing botol kultur yang telah disterilisasi diisi media sebanyak $50 \mathrm{ml}$. Kemudian botol kultur ditutup dengan alumunium foil dan diikat dengan karet gelang. 


\section{Pembuatan Media Knudson}

Pembuatan media dilakukan dengan cara menimbang bahan-bahan kimia yang digunakan sesuai komposisi media Knudson. Masing-masing bahan dilarutkan sendiri-sendiri dengan akuades.Setelah bahan dilarutkan, kemudian semua bahan dicampurkan ke dalam beaker glass. Selanjutnya, air kelapa ditambahkan sebanyak $150 \mathrm{ml}$, gula sebanyak $20 \mathrm{~g}$, dan kentang $150 \mathrm{~g}$. Setelah itu, akuades ditambahkan hingga volumenya sebesar $980 \mathrm{ml}$. Media dihomogenkan menggunakan magnetic stirrer. $\mathrm{pH}$ media diukur sebesar 5,8. Apabila media terlalu asam, maka ditambah $\mathrm{NaOH}$ 1N.Namun, jika terlalu basa ditambah $\mathrm{HCl} 1 \mathrm{~N}$. Selanjutnya, agar dimasukkan sebanyak $8 \mathrm{~g}$ dan arang sebanyak 1 g.Akuades ditambahkan hingga volume media mencapai 1000 ml.Media dipanaskan sampai mendidih. Selanjutnya, masing-masing botol kultur yang telah disterilisasi diisi media sebanyak $50 \mathrm{ml}$. Kemudian botol kultur ditutup dengan alumunium foil dan diikat dengan karet gelang.

\section{Pembuatan Media Modifikasi}

Pembuatan media dilakukan dengan cara menimbang bahan-bahan kimia yang digunakan sesuai komposisi media Modifikasi. Kemudian air kelapa ditambahkan sebanyak $150 \mathrm{ml}$, gula sebanyak $20 \mathrm{~g}$, dan kentang $150 \mathrm{~g}$. Setelah itu, akuades ditambahkan hingga volumenya sebesar $980 \mathrm{ml}$. Larutan media dihomogenkan menggunakan magnetic stirrer. $\mathrm{pH}$ media diukur sebesar 5,8. Apabila media terlalu asam maka ditambah $\mathrm{NaOH}$ 1N.Namun, jika terlalu basa ditambah $\mathrm{HCl} 1 \mathrm{~N}$. Selanjutnya, agar dimasukkan sebanyak $8 \mathrm{~g}$ dan arang sebanyak $1 \mathrm{~g}$. Akuades ditambahkan hingga volume media mencapai $1000 \mathrm{ml}$. Media dipanaskan sampai mendidih. Selanjutnya, masing-masing botol kultur yang telah disterilisasi diisi media sebanyak $50 \mathrm{ml}$. Kemudian botol kultur ditutup dengan alumunium foil dan diikat dengan karet gelang.

Botol kultur yang berisi media perlakuan dimasukkan ke dalam autoklaf dan ditata secara vertikal, kemudian autoklaf ditutup rapat. Serilisasi media dilakukan dengan tekanan $0,15 \mathrm{MPa}$ dan suhu $121^{\circ} \mathrm{C}$ selama 20 menit.

Penanaman eksplan dilakukan dengan cara mengambil plantlet dari dalam botol menggunakan pinset, laluplantlet diletakkan di dalam cawan petri yang telah di alasi dengan kertas saring steril. Plantlet dipotong menggunakan scalpel. Planlet yang ditanam berupa satu stek dengan satu daun.Daun paling ujung dibuang terlebih dahulu, kemudian tanaman krisan distek sesuai dengan pembagian blok yang menggunakan letak ruas batang. Ruas batang pertama sebagai blok pertama, kemudian disusul ruas dibawahnya sebagai blok. kedua, blok ketiga, dan blok keempat. Stek atau eksplan ditanam ke dalam botol kultur yang telah berisi media perlakuan. Mulut botol dipanaskan di atas api bunsen dan ditutup dengan aluminium foil serta wraper. Selanjutnya, botol kultur diikat dengan karet gelang. Botol kultur yang telah berisi stek diletakkan di dalam rak kultur dengan suhu antara $24^{\circ} \mathrm{C}$ dan $26^{\circ} \mathrm{C}$.

\section{Hasil dan Pembahasan}

\section{Pengaruhmedia kultur terhadap saat munculnya tunas pada stek krisan}

Hasil analisis ragam pengaruh media kultur terhadap saat muncul tunas krisan menunjukkan bahwa media kultur in vitromampumemberikan pengaruh yang berbeda terhadap saat muncultunas pada stek krisan. Hal ini disebabkan oleh ke empat media kulturin vitro yang digunakan mengandung unsur hara makro dan unsur mikro yang berbeda.

Tabel 1. Uji BNT pengaruh media kultur terhadap saat munculnya tunas pada stek krisan (hari)

\begin{tabular}{|c|c|}
\hline Perlakuan & Rerata \\
\hline Media MS & $7,00 \mathrm{a}$ \\
\hline Media V\&W & $8,75 b$ \\
\hline Media Knudson & $9,00 \mathrm{~b}$ \\
\hline Media Modifikasi & $11,5 \mathrm{bc}$ \\
\hline BNT 0,05 & 1.07 \\
\hline
\end{tabular}

Tabel 2. Uji BNT pengaruh pengelompokan ruas terhadap saat munculnya tunas pada stek krisan (hari)

\begin{tabular}{|c|c|}
\hline Kelompok & Rerata \\
\hline I & $8,25 a$ \\
\hline II & $9,75 \mathrm{~b}$ \\
\hline III & $9,5 \mathrm{~b}$ \\
\hline IV & $8,75 a$ \\
\hline BNT 0,05 & 1,07 \\
\hline
\end{tabular}

Tabel 1. menunjukkan bahwa saat muncul tunas paling cepat adalah stek krisan yang ditumbuhkan pada media MS. Sementara itu, inisiasi munculnya tunas krisan pada media modifikasi paling lambat. Hal ini disebabkan oleh kandungan unsur hara makro dan unsur hara mikro yang tersediapada masing-masing media kultur berbeda. Semua mediamengandung air kelapa dan kentang, kecuali pada media MS tidak ditambahkan kentang, karena media MS merupakan media yang komposisinya paling lengkap dibandingkan komposisi media kultur yang lain. Burnet \& Ibrahim (1973) dalam George \& Sherrington (1984) menambahkan bahwa penambahan air kelapa ke dalam media MS berhasil menumbuhkan eksplan stek krisan menjadiplanlet yang paling baik.Penambahan air 
kelapa dapat memacu pertumbuhan kalus dan meningkatkan pertumbuhan jaringan serta morfogenesis.

Hasil analisis ragam terhadap saat muncul tunas krisan memperlihatkan bahwa kelompok memberikan hasil yang signifikan. Tabel2. menunjukkan bahwa Uji BNT pengelompokan ruas terhadap saat muncul tunas. Kelompok yang paling baik terdapat pada kelompok I dengan ratarata 8,25 hari. Hasil pada kelompok I tidak berbeda nyata dengan kelompok IV, yaitu dengan rata-rata sebanyak 8,75 hari. Kelompok ruas ke I menghasilkan waktu paling cepat memacu muncul tunas. Hal ini karena ruas ke I terletak pada zona sub apikal, dengan jaringan yang aktif membelah, dan kelompok ke IVsesuai dengan pernyataan Dwijoseputro (1980) yang menyatakan bahwa kandungan auksin paling tinggi terjadi di puncak koleoptil, sehingga kandungan auksin sekitar pucuk relatif tinggi. Sementara itu, pada kelompok IV yang terletak pada pangkal juga memiliki kandungan auksin cukup tinggi. Hal ini karena menurut Zunaidah (2011) transport auksin pada akar terjadi secara akropetal, auksin ditranspor polar dari pangkal akar menuju ke arah ujung akar melalaui parenkim disekitar jaringan vaskuler. Oleh karena itu, saat muncul tunas stek krisan selanjutnya pada kelompok IV.

\section{Pengaruh media kultur terhadap saatmunculnya akar pada stek krisan}

Hasil analisis ragam perlakuan berbagai media kulturin vitro dan pengelompokan ruas terhadap saat muncul akar stek krisan berpengaruh sangat nyata.

Tabel 3. Uji BNT pengaruh media kultur terhadap saat munculnya akar pada stek krisan (hari)

\begin{tabular}{ll}
\hline Perlakuan & Rerata \\
\hline Media MS & $4,75 \mathrm{a}$ \\
Media VW & $5,00 \mathrm{a}$ \\
Media Knudson & $11,25 \mathrm{~b}$ \\
Media Modifikasi & $12,50 \mathrm{~b}$ \\
\hline BNT 0,05 & 1,66 \\
\hline Keterangan: angka yang diikuti oleh huruf yang sama \\
\multicolumn{2}{r}{ tidak berbeda nyata pada taraf uji 0,05 }
\end{tabular}

Tabel 4. Uji BNT pengaruh pengelompokan ruas terhadap saat munculnya akar pada stek krisan (hari)

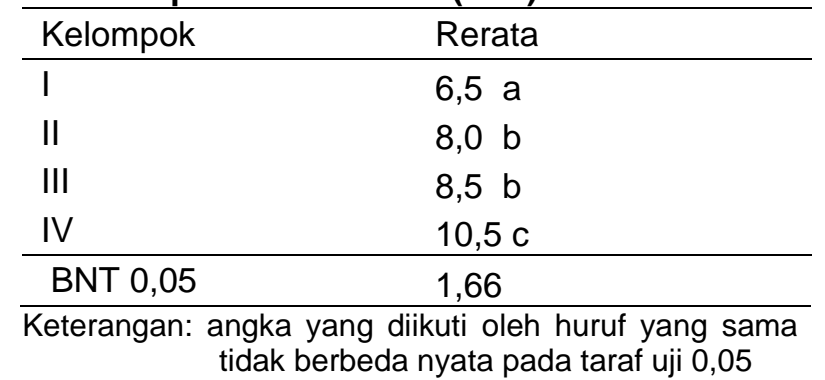

Tabel 3. uji BNT perlakuan media kultur in vitro terhadap saat muncul akar stek krisan menunjukkan bahwa media MS mampu memacu muncul akar stek krisan paling cepat apabila dibandingkan dengan muncul akar stek pada media lainnya. Sementara itu, saat muncul akar pada stek krisan pada media modifikasi menunjukkan hasil yang paling lambat dibandingkan dengan media kultur lainnya. Menurut Muhit (2007) akar stek krisan mulai terbentuk pada saat umur plantlet 12-15 hari setelah tanam.Tahapan pembentukan akar dimulai dari pembentukan kalus embriogenik pada sel-sel penyusun akar, dilanjutkan dengan inisiasi pembentukan akar pada sel-sel yang dekat dengan jaringan pengangkut yang menjadi meristimatik. Selanjutnya, akar membentuk primordia akar di dalam jaringan. Primordia tersebut akan terus tumbuh dan membentuk akar ke luar jaringan. Empat tahapan pembentukan akar pada tanamanherba pada umumnya berlangsung sekitar 1 dan 7 hari.

Berdasarkan Tabel 4. saat muncul akar krisan yang paling baik yaitu terdapat pada kelompok I dengan rata-rata 6,5 hari.Hal ini sesuai dengan pernyataan dari Sutejo (1994) yang menyatakan bahwa pertumbuhan akar yang optimal terutama terjadi pada kelompok I yaitu pada ruas teratas pada bagian zona pendewasaan. Hal ini karena kandungan auksin pada ruas teratas cukup tinggi.

Brenner et al. (2007) menjelaskan bahwa pembentukan akar umumnya dimulai dengan memindahkan indol acetic acid (IAA) yang diproduksi oleh pucuk tanaman ke bagian batang yang luka. Hal ini dapat menstimulasi pembentukan akar. Konsentrasi IAA dalam jaringan batang yang terluka meningkat tajam pada hari pertama setelah pemotongan. Tahap awal, 24 jam setelah pemotongan, umumnya stek krisan tidak sensitif terhadap hormon, sehingga IAA bertindak sebagai aktivator pembentukan akar. Selanjutnya, kandungan IAA akan menurun pada hari ketiga. Sel-sel penyusun akar aktif membelah diikuti dengan pembentukan primordia akar, pembentukan akar sampai akar tumbuh dan berkembang.Auksin umumnya berperan penting dalam inisiasi pembentukan akar. Peran auksin akan optimal bila faktor lingkungan sekitar juga optimal. Sementara itu, Hendaryono (1998) dalam Widiyatmanto et al. (2012) menyatakan kalsium dapat memacu munculnya akar lebih cepat.Kalsium berfungsi mengatur permiabilitas membran sel. Akibatnya, kalsium dapat melewati membran sel dengan baik.Kalsium berpengaruh terutama dalam hal pembentukan ujung bulu-bulu akar.

\section{Pengaruhmedia kultur terhadap panjang tunas pada stek krisan}

Hasil analisis ragam perlakuan berbagai media kultur terhadap panjang tunasmenunjukkan 
bahwa media kultur berpengaruh nyata dalam mempengaruhi panjang tunas.

Tabel 5. Uji BNT pengaruh media kultur terhadap panjang tunas pada stek krisan $(\mathbf{c m})$

\begin{tabular}{|c|c|}
\hline Perlakuan & Rerata \\
\hline Media MS & $4,76 \mathrm{~b}$ \\
\hline Media V\&W & $3,60 \mathrm{~b}$ \\
\hline Media Knudson & $4,95 \mathrm{~b}$ \\
\hline Media Modifikasi & $1,60 \mathrm{a}$ \\
\hline BNT 0,05 & 1,36 \\
\hline
\end{tabular}

Hasil uji BNT pada Tabel 5.pengaruhmedia terhadap panjang tunas stek krisan menunjukkan bahwa media Knudson mampu memacu panjang tunas sebesar $4,95 \mathrm{~cm}$. Panjang tunas pada media Knudson lebih baik daripada panjang tunas pada media MS. Hal ini karena di dalam media Knudson juga ditambahkan bahan organik berupa kentang sebanyak 150 gram dan air kelapa sebanyak $150 \mathrm{ml}$. Sementara itu, di dalam media MS hanya ditambahkan air kelapa sebanyak 150 $\mathrm{ml}$. Kandungan karbohidrat pada kentang yang menjadi penyusun dalam media Knudson merupakan komposisi yang paling sesuai untuk memacu panjang tunas tanaman krisan. Menurut Widiastoety \& Bahar (1995) karbohidrat merupakan sumber karbon dan energi.Sumber karbon dan energi yang sering digunakan adalah sukrosa dan glukosa.Senyawa-senyawa organik tersebut selain sebagai bahan bakuproses respirasi berupa ATP dan $\mathrm{NADPH}_{2}$ untuk menghasilkan energi, kedua senyawa ini juga sebagai bahan pembentuk sel-sel baru.

\section{Pengaruh media kultur terhadap jumlah daun pada tunas stek krisan}

Hasil analisis ragam perlakuan berbagai media kultur terhadap jumlah daun menunjukkan bahwa aplikasi media kultur cukup signifikan dalam memacu jumlah daun stek krisan.

Tabel 6. Uji BNT pengaruh media kultur terhadap jumlah daun pada stek krisan

\begin{tabular}{ll}
\hline Perlakuan & Rerata \\
\hline Media MS & $10,00 \mathrm{~b}$ \\
Media V\&W & $9,00 \mathrm{~b}$ \\
Media Knudson & $9,62 \mathrm{~b}$ \\
Media Modifikasi & $6,50 \mathrm{a}$ \\
\hline BNT 0,05 & 2,24 \\
\hline
\end{tabular}

Keterangan: angka yang diikuti oleh huruf yang sama tidak berbeda nyata pada taraf uji 0,05

Hasil uji BNT pada Tabel6.menunjukkan bahwa pembentukan daun paling banyak diperoleh pada stek yang ditumbuhkan pada media MS, sebanyak 10 helai daun.Jumlah daun stek krisan yang ditanam pada media MS tidak berbeda jauh dengan jumlah daun pada media Knudson sebanyak 9,62 helai daun.

Hasil penelitian Matatula (2003) menggunakan bahan organik air kelapa dengan perlakuan media MS $50 \%$ dan $50 \%$ air kelapa ternyata memberikan hasil yang terbaik pada pertumbuhan tanaman stek krisan secara in vitro. Menurut Morel (1974), air kelapa merupakan endosperm dalam bentuk cair yang mengandung unsur hara dan zat pengatur tumbuh, sehingga dapat menstimulasipertumbuhan. Air kelapa juga mengandung zeatin yang termasuk ke dalam golongan sitokinin. Zeatin bermanfaat untuk memacuterjadinya proses organogenesis daunyang dapat mempercepat pertumbuhan daun. Berdasarkan hasil penelitian Sari et al. (2011)jumlah daun terbanyak pada perlakuan penambahan air kelapa $300 \mathrm{ml} / \mathrm{l}$. Menurut Wuryaningsih \& Sutater (1992) jumlah daun berhubungan erat dengan jumlah cabang dan tinggi tanaman.Semakin banyak jumlah cabang yang terbentuk dan semakin tinggi suatu tanaman, maka semakin banyak pula jumlah daun yang terbentuk.

\section{Pengaruh berbagai media kultur terhadapjumlah akar pada stek krisan}

Hasil analisis ragam pengaruh berbagai media kultur terhadap jumlah akar stek krisan menunjukkan hasil yang tidak signifikan.

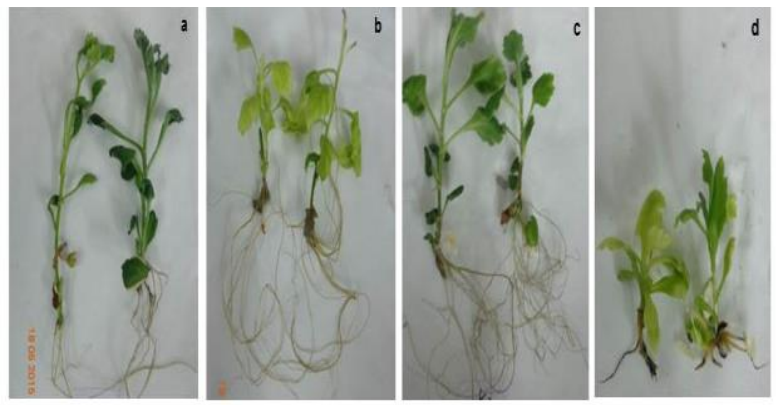

Gambar 4.7.Pertumbuhan Stek Krisan pada Berbagai Media Kultur (a) Media MI (b) Media I \&W (c) Mededia Knduson (d) Media Modifikas

Hipotesis penggunaan media kultur in vitro berpengaruh terhadap pertumbuhan stek tanaman krisan. Media modifikasi merupakan media alternatif selain media MS untuk pertumbuhan stek krisan secara in vitro tidak sesuai dengan hasil yang diperoleh, karena komposisi media modifikasi sangat sederhana. Hasil pengamatan secara visual menunjukkan bahwa pertumbuhan stek krisan pada berbagai media kulturin vitro yang paling baik ditunjukkan pada perlakuan media Knudson. Secara visual dapat dilihat dari panjang tunas dan jumlah daun yang dihasilkan pada media Knudson paling baik. Media selain MS yang cukup baik memacu pertumbuhan stek krisan adalah media Knudson. Media ini dapat dijadikan media alternatif dalam memperbanyak stek krisan secarain vitro. 


\section{Simpulan}

Berdasarkan hasil penelitian diatas disimpulkan bahwa media kultur berpengaruh terhadap pertumbuhan stek tanaman krisan

\section{Daftar Referensi}

Brenner, M.L., Wolley, D.J, Sjut, V. \& Salerno, D.,1987. Analysis of Apical Dominance in relation to IAA Transport. Hortscience, 25(5), pp. 833-835.

Dixon, R.A., 1985. Plant Cell Culture a Pratical Approach, IRL, Press, Limited, Oxford, Washington DC,4.

Dwijoseputro, 1980.Pengantar Fisiologi Tumbuhan. Jakarta: Penerbit PT. Gramedia.

George, E.F \& Sherington, P.D., 1984. Handbook of Plant Propagation by Tissue Culture. England (GB): Eastern Press Ltd.709p.

Marwoto, B., 2005. Standar Prosedur Operasional Budidaya Krisan Potong. Direktorat Budidaya Tanaman Hias. Jakarta: Direktorat Jenderal Hortikultura. Departemen Pertanian.

Matatula, A.J., 2003. Substitution of MS Medium with Coconut Nater and Gandasil-D on Chrysanthemum Tissue Culture.Eugenia., 9(4), pp. 203-211.

Morel, G.M. 1974. Clonal multiplication of Orchids., (C. Withner eds.) Scientific Wiley, NewYork. pp. 169-222.

Muhit, A., 2007., Teknik Produksi Tahap Awal Benih Vegetatif Krisan (Chrysanthemum morifolium R.). Buletin Teknik Pertanian, 12 (1), pp. 14-18.

Purwanto, A. W. \& Martini, T., 2009.Krisan : Bunga Seribu Warna. Yogyakarta: Kanisius.

Puspitasari, I., 2009. Budidaya Bunga Potong Krisan (Chrysanthemum sp.) di secara in vitro. Media Knudson merupakan media alternatif selain media MS yang cukup baik dalam meningkatkan pertumbuhan stek tanaman krisan secara in vitro.

Kelompok Tani Udi Makmur Wonokerso, Hargobinangun, Pakem, Sleman.Skripsi. Surakarta: Jurusan Agribisnis Hortikultura dan Arsitektur Pertamanan. Universitas Sebelas Maret.

Sanjaya, L., 1996. Krisan Bunga Potong dan Tanaman Pot yang Menawan. Litbang Pertanian, 3(15), pp. 55-60.

Sari, Y.P, Manurung, H \& Asipah., 2011. Pengaruh Pemberian Air Kelapa terhadap Pertumbuhan Anggrek Kantong Semar (Paphiopedilum supardii Braem \& Loeb) pada Media Knudson Secara In Vitro. Mulawarman Scientifie, 10(2), pp. 1412-498X.

Sutejo MM. 1994. Pupuk dan Cara Pemupukan. Jakarta: Rineka Cipta.

Widiastoety, D. \& Bahar, F.A., 1995.Pengaruh Berbagai Sumber dan Kadar Karbohidrat terhadap Pertumbuhan Planlet Anggrek Dendrobium.J.Hort., 5(3), pp.76-80.

Widiyatmanto, P.P., Nurhidayati, T., \& Nurfadilah, S. 2012. Pengaruh Jenis Media dan Konsentrasi NAA (Naphthalene Acetic Acid) terhadap Pertumbuhan dan Perkembangan Biji Dendrobium capraJ.J Smith Secara In Vitro. Skripsi.Biologi FMIPA ITS, Surabaya.

Wuryaningsih, S. \& Sutater, T., 1992.Pengaruh Dosis $\mathrm{N}$ dan $\mathrm{K}$ terhadap Pertumbuhan dan Produksi Bunga Krisan Putih Lokal Cipanas.J. Hort., 2 (3), pp. 23-27.

Zunaidah, S. 2011. Laporan Praktiukum Fisologi Tumbuhan Pengaruh Hormon Auksin terhadap Pertumbuhan dan Perkembangan Akar. (4), pp. 1315-01. 